\title{
Guerilla Communications: Poster Responses to the Coup of 1936
}

\author{
Hilary Gordon $^{\mathrm{i}}$
}

This work explains how adaptable local poster communication strategies developed across Republican Spain in order to provide publicly fueled solutions to the highly variant community needs precipitated by nationalist coup and the emergence of social revolution in 1936. [Article copies available for a fee from The Transformative Studies Institute. E-mail address: journal@transformativestudies.org Website: http://www.transformativestudies.org $\quad$ (C2012 by The Transformative Studies Institute. All rights reserved.]

KEYWORDS: Posters, Propaganda, Spanish Civil War.

Political posters were a prevalent part of the visual fabric of Republican Spain from the first days of the civil war. Spain's foreign minister, Avarez de Vayo narrated this scene in his memoir,

"Full-color posters, banners, and fliers, brandishing dramatic swaths of red and black or blue and yellow were all over the city: along the streets, taped to windows, tacked up on kiosks in every public square, on the interior walls of office buildings and private homes, in all of the subway stations, on the sides of busses, trucks, and even trains. By the second week of the war, early in July of 1936, they were already defining the public space of major cities."1

This profuse consumption and publication of public imagery in the Republican zone was necessitated and enabled by the popular nature of the resistance during the first year of the war. The visually based, symbol

\footnotetext{
${ }^{\text {i }}$ Hilary Gordon is a doctoral candidate in history and archives at Claremont Graduate University. She received her BA and MA from Tulane University and holds the Ida Lloyd Crowtty endowed fellowship for American History. Address correspondence to: Hilary Gordon, 649 Blanchard Place, Claremont, California 91711; tel: 985-290-6839; e-mail: hillanngordon@gmail.com.
} 